\title{
Mixed embeddedness of immigrant entrepreneurs in microstates. The case of Andorra
}

\author{
Judith Pampalona, Miranda J Lubbers y José Luis Molina - Universitat \\ Autònoma de Barcelona, GRAFO - Departament d'Antropologia social i \\ cultural ${ }^{1}$
}

DOI: https://doi.org/10.5565/rev/periferia.684

\begin{abstract}
The theory of mixed embeddedness has been empirically tested in several countries showing how immigrant entrepreneurs utilize network resources coming from both the country of origin and residence, including institutions. Nevertheless, little attention has been paid to the networks of immigrant entrepreneurs residing in a microstate. Specific features of microstates may affect the way in which migrant entrepreneurs develop their ventures. Therefore, we collected the personal networks of 40 entrepreneurs through a mixed-method approach, in order to understand the mechanisms through which the microstate context affects entrepreneurs' support networks. Our results indicate that in Andorra migrants need higher levels of support from people settled in or close to Andorra in comparison to immigrants in other contexts. Contacts in the sending country only play a secondary role.
\end{abstract}

Keywords: Microstate; Immigrant entrepreneurs; Personal networks; Mixed embeddedness; Social Support; Legal restrictions

Resumen: Integración mixta de empresarios inmigrantes en microestados. El caso de Andorra

La teoría de la integración mixta se ha probado empíricamente en varios países mostrando cómo los empresarios inmigrantes utilizan recursos de red provenientes tanto del país de origen como de residencia, incluidas las instituciones. Sin embargo, se ha prestado poca atención a las redes de empresarios inmigrantes que residen en un microestado. Las características específicas de los microestados pueden afectar la forma en que los empresarios migrantes desarrollan sus emprendimientos. Por lo tanto, recopilamos las redes personales de 40 empresarios a través de un enfoque de métodos mixtos, con el fin de comprender los mecanismos a través de los cuales el contexto de los microestados afecta las redes de apoyo de los emprendedores. Nuestros resultados indican que en Andorra los inmigrantes necesitan mayores niveles de apoyo de personas asentadas en o cerca de Andorra en comparación con inmigrantes en otros contextos. Los contactos en el país de origen solo juegan un rol secundario.

Palabras clave: Microestado; Emprendedores inmigrantes; Redes personales; Integración mixta; Apoyo social; Restricciones jurídicas

\footnotetext{
${ }^{1}$ Enviar correspondencia a: José Luis Molina joseluis.molina@uab.cat
} 
Judith Pampalona, Miranda J Lubbers y José Luis Molina, Mixed embeddedness of immigrant entrepreneurs in microstates. The case of Andorra.

Perifèria 24(1), junio 2019 revistes.uab.cat/periferia

\section{Introduction}

Immigrant entrepreneurship has been widely studied by social scientists in the last decades, focusing mainly on the motivations and opportunities that allow immigrants to start businesses in the society of residence, and the strategies that helped them succeed. The literature explains this phenomenon as an attempt of individuals to escape marginal positions in the labour market (Aldrich and Waldinger 1990; Mahuteau et al., 2011) or as an outcome of the interplay between cultural factors and the reception context (Kloosterman et al., 1999). Due to the lack of economic resources that characterize many migrant populations, most attention has been paid to the social and cultural resources mobilized by immigrants along the business cycle. Among others, it has been hypothesized that immigrant entrepreneurs take advantage of their mixed embeddedness, i.e., the simultaneous embeddedness in the mainstream institutions, economy and society, and in the co-ethnic community (Kloosterman et al., 1999). The term refers to a complex interplay between the larger legal, institutional and social context of the mainstream society and the micro-level embeddedness in social networks of both the native population and the co-ethnic community. Involvement in the local and transnational co-ethnic communities is thought to allow migrants to engage in informal economic activities that help them survive in market conditions shaped by the larger context.

Empirical evidence supporting this hypothesis has been typically collected in large countries such as the USA (Price and Chacko, 2009), New Zealand (Cain and Spoonley, 2013) and also in European countries (Ram et al., 2008; Valenzuela-García et al., 2014), but little attention has been paid to this topic in microstates. This case is of interest however, because, as some authors have pointed out, microstates are characterized by specific political, legal and geographical frameworks (Baldacchino, 1993; Grydehøj, 2011) that could affect how immigrant entrepreneurs build and use their support networks, helping us understand better how migrants' use of social networks is contingent on regulatory frameworks.

This research seeks to contribute to the extant literature by testing whether the 
Judith Pampalona, Miranda J Lubbers y José Luis Molina, Mixed embeddedness of immigrant entrepreneurs in microstates. The case of Andorra.

Perifèria 24(1), junio 2019 revistes.uab.cat/periferia

mixed embeddedness theory is applicable in microstate contexts in the same way it is in larger countries (especially in European ones, where most evidence for the theory was collected). In other words: does involvement in both co-ethnic and native networks also have a positive effect on ethnic entrepreneurship in the particular conditions of micro-states? To answer this research question, we have focused on immigrant entrepreneurs in the Andorran context, which exhibits typical microstate features, as described in the section about the context in Andorra. In order to understand how support networks of immigrant entrepreneurs diverge from those of native entrepreneurs, we have also collected data of a few native entrepreneurs in this context. Studies typically do not compare the networks of migrants to those of natives, so that it is unclear to what extent certain network strategies are typical for migrant populations.

This paper is organized as follows. Next section reviews the existing literature on immigrant entrepreneurship and the importance of support networks within this field, and relates this to the microstates literature. Section 3 explains in detail the studied microstate context (the Principality of Andorra). Section 4 and 5 present, respectively, the methodology and the results, the latter through three main profiles of entrepreneurs and their support networks. In the sixth section, we draw conclusions and give suggestions for future research.

\section{Literature}

The emergence of immigrant entrepreneurship has been explained mostly in terms of the cultural background of entrepreneurs and the characteristics of the host context. Among the different theoretical perspectives regarding this topic are: (a) the interactive perspective, explaining the emergence of immigrant businesses in terms of the demands of immigrant communities in a specific opportunity context (Light and Gold, 2000; Waldinger, 1986), (b) the culturalist perspective focused on the cultural tradition of running businesses among immigrants of certain countries of origin (Raijman and Tienda, 2003), (c) the ecological perspective, which has indicated that immigrants occupy free market niches abandoned by natives (Aldrich and Reiss, 
Judith Pampalona, Miranda J Lubbers y José Luis Molina, Mixed embeddedness of immigrant entrepreneurs in microstates. The case of Andorra.

Perifèria 24(1), junio 2019 revistes.uab.cat/periferia

1976), and (d) the social embedding perspective, which takes into account the legislative and social context as factors explaining immigrant self-employment (Guarnizo, 2003; Portes et al., 1999; Shane and Venkatamaran, 2000).

Regarding the latter approach, there is evidence of the relevance of personal contacts in the starting up and the developing of a business, since personal networks constitute the most important social resource within the entrepreneurial relationships (Arjona and Checa, 2006). Social capital in terms of material resources flowing within personal networks and the knowledge about the surrounding context (market, social needs, opportunity structures, niches, etc.) (Lin, 2001) are crucial to access the different opportunities given by the market structure. In this sense, it is necessary for entrepreneurs to select the best available resources from their personal networks in order to establish fruitful collaborations and to be well connected to the opportunity structure (Krebs and Holley, 2002). The strength of different ties in terms of emotional closeness affects their success. Whereas stronger ties are crucial at the very beginning as they give emotional, logistic and even economic support, the weaker ones tend to be relevant to access new information and opportunities that will help the development of the business (Granovetter, 1973).

Apart from the strength of the network ties, the concept of mixed embeddedness stresses the importance for migrant entrepreneurs of having ties with both natives and co-ethnics, as this helps them to adapt to a host society and promotes their upward social mobility (Kloosterman et al., 1999). In particular, ties to the co-ethnic community are thought to allow migrants to engage in informal economic activities that help their businesses survive in tough market conditions. Local co-ethnics are for example thought to be employed as informal work force, and transnational ties with co-ethnics can provide material resources for immigrant enterprises. This concept of 'informal economy' (Hart, 1973) appears when individuals seek to escape governmental controls in specific situations where the existing regulations are not applicable to their actual activities (Renooy, 1990). Thus, this so-called informal economy is easily associated with immigrant communities and entrepreneurs, probably due to their more difficult access to regular opportunity structures, and also 
Judith Pampalona, Miranda J Lubbers y José Luis Molina, Mixed embeddedness of immigrant entrepreneurs in microstates. The case of Andorra.

Perifèria 24(1), junio 2019 revistes.uab.cat/periferia

because of the existing legal barriers concerning their economic rights in some cases (Wilpert, 2003). Nevertheless, these informal resources are also employed by native entrepreneurial groups (Sassen, 1994) since receiving informal support from different contacts is crucial to start and maintain any business. Of course, entrepreneurs' social networks are not the only decisive aspect to run a business in a market; other factors include the legal conditions that usually constitute institutional barriers (Kloosterman, 2010) and the size of the country where the business is established (Jónsson and Saemundsson, 2006).

The mixed embeddedness theory has been generally supported for long-established migrant communities in national contexts with a larger, more complex opportunity structure, although the decisive role of ethnic social capital as a support mechanism for newcomers' businesses has been questioned in some studies on social networks (Jones et al., 2012; Sepulveda et al., 2011). Nevertheless, studies testing the mixed embeddedness theory have not been carried out in microstates. Microstates do not only represent a small geographical area, but they also exhibit some specific legislations and particular social and demographical characteristics (Baldacchino, 1993; Grydehøj, 2011). For example, many microstates exhibit a high rate of immigrant labour (Baldacchino, 1993), and this is probably one of the reasons for the creation of specific legislative frameworks that protect the small native communities in terms of identity, economy, social structure, etcetera. At the same time, this phenomenon entails the risk of falling into a technocratic system (Grydehøj, 2011; Jónsson and Saemundsson, 2006), since the voting community (those with politic rights) is a minority in the general population and laws are therefore likely to protect or benefit especially that particular group.

Some of the most common features of microstates that may affect immigrant entrepreneurs are the following. First, the small size of the country itself, which is thought to facilitate individuals' integration in society and to provide new opportunities but it may also challenge economic growth (Armstrong and Read, 2000). Second, the development strategies in terms of both governance and economy. These strategies often cannot be applied in larger contexts, but they are 
Judith Pampalona, Miranda J Lubbers y José Luis Molina, Mixed embeddedness of immigrant entrepreneurs in microstates. The case of Andorra.

Perifèria 24(1), junio 2019 revistes.uab.cat/periferia

less problematic in small countries, where government is closer to the community (Baker, 1992; Grydehøj, 2011). Third, and finally, their particular, often restrictive policies concerning migrants' political and economic rights. These conditions affect the way in which immigrants may integrate into society, and the way of accessing resources in case they plan to become entrepreneurs.

The next section describes the specific conditions of Andorra, our research area.

\section{The context of Andorra: Restrictions to protect identity and social structure}

Andorra is a microstate located in the middle of the Pyrenees. Due to its small size and its location between two large states, Andorra has adopted a particular economic, social and political structure based on the preservation of its identity. This situation is similar to that of other microstates.

Andorra is a multicultural society where immigrants outnumber natives (at a ratio of 65:35), and where many businesses are led by immigrants, although they had to deal with a restrictive legal system until June 2012. The main goal of these legislative restrictions was to protect the identity and the social structure of the native society. Until June 2012, the required period of residence to obtain economic rights was 20 years for all nationalities except for Spaniards, Portuguese and French, for whom the period was ten years due to a bilateral agreement between those countries and Andorra. In case of not fulfilling the described conditions, that is, if the entrepreneur decided to start an initiative before the established period, an Andorran major shareholder was required.

One solution to circumvent these restrictions was to obtain a figurehead. In fact, this solution was adopted by the majority of immigrant entrepreneurs. This is very common in contexts where legal restrictions concerning immigrants' economic rights are applied, not only in microstates but also in countries like Germany (Pütz et al., 2007) or Austria (Kurtoglu, 2007). The figurehead is an individual who allows his or her name to be used for someone else's business without having responsibilities, interests, or duties. This can be either remunerated or not, often depending on the 
Judith Pampalona, Miranda J Lubbers y José Luis Molina, Mixed embeddedness of immigrant entrepreneurs in microstates. The case of Andorra.

Perifèria 24(1), junio 2019 revistes.uab.cat/periferia

closeness of the figurehead to the entrepreneur, but in any case it is risky as it is illegal.

Businesses in Andorra tend to be directed to the general public and focused on the main economic sectors of the country, that is, commerce, services, tourism, hotel trade and the construction sector, although the latter has decreased in the last years due to the economic crisis. Financial trade, though being one of the most important sectors in the country, is dominated mostly by natives, who own large businesses while immigrants (or 'residents', as they are called in this context) tend to have small and medium enterprises in general.

The economic crisis of the last decade provoked the departure of many residents and many of the businesses established in the country were forced to close their doors. As a consequence, the government considered the need to change some aspects of the economic and legal structure in order to facilitate the entry of human and economic capital into the country and the creation of new businesses and labour vacancies. One of the applied measures was the creation of a new economic opening law (10/2012 of 21st June of Foreigner Investments within the Principality of Andorra) that lifted the prior restrictions concerning economic rights to immigrants and individuals non-established within the country. This new legislative application will probably have important social repercussions such as the entrance of new immigrant groups (which do currently not have any presence within Andorra) or changes in the entrepreneurs' network structure in terms of the transnational scope of received support.

Taking into account the existing particularities of the Andorran context, we hypothesized that the personal support networks of immigrant entrepreneurs in a microstate context have a different structure than typically observed in other countries, due to the high concentration of population in a small area and also due to the existing legislative structure. In this context, we expected that the mixed embeddedness theory (Kloosterman et al., 1999) would be challenged. Due to the restrictive legislative system, immigrant entrepreneurs will be embedded in the Andorran opportunity structure, but not necessarily in their co-ethnic community in 
Judith Pampalona, Miranda J Lubbers y José Luis Molina, Mixed embeddedness of immigrant entrepreneurs in microstates. The case of Andorra.

Perifèria 24(1), junio 2019 revistes.uab.cat/periferia

Andorra or in their country of origin. Once they have assumed the right of selfemployment, they may count on a support network where social capital resources can be more relevant than cultural similarity. We expected that links to the country of origin or the co-ethnic community are primarily relevant in emotional or personal life terms. We further expected that due to the small size of the country and the closeness of the border, cross-border collaborations will happen more easily having either the role of a partner or an employee, being relevant mainly for logistical support. Nevertheless, we expect that cross-border collaboration and transnational networks will have very different characteristics in structural terms.

\section{Methods}

\section{Sample}

Between January and December 2013, data were collected from 40 immigrant and native entrepreneurs whose businesses were established in different areas of the Principality of Andorra. In order to investigate whether migrants' support networks follow the same pattern as those of native Andorrans, we included ten native Andorrans in our sample. Four other cases were neither natives nor immigrants, but an important category in many microstates nonetheless: the so-called 'cross-border workers'. They lived in Spain, close to the border with Andorra (at most $60 \mathrm{~km}$ away from the border) and crossed the border on an almost daily basis to go to their enterprise. Most of them had only started their businesses recently, under the new law. To control for the abolition of the restrictions concerning economic rights of immigrants in 2012, we also interviewed four new immigrant entrepreneurs. These had started their businesses in the past three years, under the new law. For the 22 remaining (non-native) cases, we intended to maximize variation in the sample in three aspects that may condition the contents and structure of their support networks: (a) respondents' cultural closeness to the Andorran society, which may influence the integration into the society; (b) the geographical closeness of their country of origin, since it will influence the density of the network and (c) their period of residence in Andorra. This last variable was high in almost all of the studied cases 
Judith Pampalona, Miranda J Lubbers y José Luis Molina, Mixed embeddedness of immigrant entrepreneurs in microstates. The case of Andorra.

Perifèria 24(1), junio 2019 revistes.uab.cat/periferia

because it has been supposed to be one of the compulsory conditions to run a business in Andorra before 2012. Of course this variable is correlated with the other two variables, as the longer the person resided in Andorra, the more integrated he or she may be and also the denser will be the network, as a consequence of having more and more contacts within the national area (and national contacts tend to be highly connected because of the small context size).

Of all the respondents, 24 were males and 16 were females. Their age ranged from 29 to 67 years, with an average of 48 years. The immigrants were originally from Spain, Portugal, France and India. Immigrants had started their businesses about 13 years ago on average, while natives were already in business for about 22 years on average. The four new migrant entrepreneurs as well as three of the cross-border workers had started their business since 2012. These differences in the maturity of the business are also partly reflected in its success. When we classify all enterprises by growth stage (Churchill and Lewis, 1983), we can see that migrants' enterprises were mostly in the primary stages of existence $(n=7)$ and survival $(n=8)$, but 7 migrant entrepreneurs had their businesses in the more advanced stages of success and take off. The four cross-border workers were similarly distributed across these stages ( 1 in the existence stage, 2 in the survival, and 1 in the success stage). All the new migrants had their enterprises in the first stage, that of existence. Natives on the other hand were spread more widely over all the five growth stages, namely existence (1), survival (3), success (2), take-off (1) and resource maturity (3).

\section{Procedure}

A mixed methodology has been applied (Creswell, 2003), combining structured and semi-structured interviewing. The structured part focused on collecting basic data of the enterprise and the entrepreneur and on collecting comparable information about the personal support networks. For this purpose, a questionnaire was designed and applied with the software Egonet. The questionnaire contained four modules:

(1) Questions about the respondent (or 'ego' in personal network terms, entrepreneurs in this case). 
Judith Pampalona, Miranda J Lubbers y José Luis Molina, Mixed embeddedness of immigrant entrepreneurs in microstates. The case of Andorra.

Perifèria 24(1), junio 2019 revistes.uab.cat/periferia

(2) A list of so-called 'name generators', or questions designed to obtain a list of names of persons ('alters') who supported the creation and development of the respondent's enterprise. In this case the number requested was 22 , in order to collect both strong and weak ties.

(3) Questions regarding the characteristics of each of these network members.

(4) Questions about the relationships among these network members.

In order to name the different contacts appearing in the network (module b), six name generators were used:

- Please name the people who gave support to your business in terms of

(1) Economic issues

(2) Advice in administrative or legal issues

(3) Partnership or figurehead

(4) Logistic issues

(5) Emotional support

(6) Other support

These networks can be visualized as a set of nodes (representing the network members elicited in module 2) and edges (representing the relationships among network members on the basis of module 4). Characteristics of network members (module 3 ) can be visualized by varying the size, colour and shape of the nodes. The respondent does not appear as a node within the visualization of his/her network since he/she is by default linked to all the contacts, so his/her presence would only blur the information in the graph. The semi-structured part of the interview on the other hand included questions about the individual's migratory trajectory, his/her experience in starting and running his/her own business, and the specific opportunity structures encountered. This part also focused on obtaining a more detailed explanation of the network structure as well as of the role and importance of each single contact in the entrepreneur's network for the survival and success of the business. The qualitative data also allowed us to know the role played by the respondent him-or herself in the creation of his/her own network. This part is essential to complement, interpret and contrast the quantitative measures of the network. 
Judith Pampalona, Miranda J Lubbers y José Luis Molina, Mixed embeddedness of immigrant entrepreneurs in microstates. The case of Andorra.

Perifèria 24(1), junio 2019 revistes.uab.cat/periferia

\section{Results: Cases of entrepreneurs and their network models}

Table 1 shows the composition of the support networks for the four groups of respondents. We have distinguished between five types of network members based on (a) the country of origin of the network members, (b) the country of residence of the contacts, that is, if they are settled in Andorra or abroad, and (c) in case the country of residence is France or Spain, the precise location of the contacts (geographical closeness to the Andorran border). Through the narratives of each entrepreneur, we were able to distinguish between contacts abroad that were 'transnational' and contacts that were simply 'cross-border' (max. $60 \mathrm{~km}$ from the border or 1 hour driving from the border in case the access is difficult). We make a difference between these two concepts since the obtained network structure in these cases changes significantly depending on this variable: whereas networks with transnational alters are less tightly connected and exhibit important numbers of weak ties, the cross-border networks are denser and with more strong ties. At a first glance, we could treat transnational and cross-border cases as similar since both are settled abroad and the legislative structure is the same in all the Spanish or French areas no matter how close they are to the border. Nevertheless, informal economic activities have emerged historically in border areas.

\begin{tabular}{|c|c|c|c|c|c|c|}
\hline \multirow{2}{*}{ Respondent } & \multicolumn{3}{|c|}{ Local ties } & \multirow{2}{*}{$\begin{array}{c}\text { Cross- } \\
\text { border } \\
\text { ties }\end{array}$} & \multirow{2}{*}{$\begin{array}{c}\text { Transnational } \\
\text { ties }\end{array}$} & \multirow{2}{*}{$\begin{array}{l}\text { Network } \\
\text { size }\end{array}$} \\
\hline & $\begin{array}{c}\text { Co- } \\
\text { nationals }\end{array}$ & $\begin{array}{l}\text { Other } \\
\text { migrants }\end{array}$ & Natives & & & \\
\hline Migrants & 7.0 & 4.0 & 7.0 & 1.2 & 3.5 & 22.7 \\
\hline $\begin{array}{l}\text { New } \\
\text { migrants }\end{array}$ & 4.0 & 1.5 & 4.0 & 2.0 & 11.8 & 23.3 \\
\hline Natives & - & 7.5 & 8.8 & 0.9 & 6.8 & 24.0 \\
\hline $\begin{array}{l}\text { Cross-border } \\
\text { workers }\end{array}$ & 3.0 & 1.0 & 4.5 & 7.3 & 7.8 & 23.5 \\
\hline
\end{tabular}

Table 1. Composition of support networks of different types of respondents 
Judith Pampalona, Miranda J Lubbers y José Luis Molina, Mixed embeddedness of immigrant entrepreneurs in microstates. The case of Andorra.

Perifèria 24(1), junio 2019 revistes.uab.cat/periferia

Table 1 shows that established migrants had a mixed embeddedness: they received support from both compatriots residing in Andorra ( 7 persons on average) and natives of Andorra (also 7 on average), and another 7.5 persons were other migrants in Andorra and people living abroad. The majority of their ties were local, with a percentage of migrants $(61 \%)$ that is quite comparable to that of the general population $(54 \%)$. For new migrants on the other hand, more than half of their support ties lived abroad ( 2 cross-border and 12 transnationally), and they received support from relatively few local compatriots and Andorrans. The situation was similar for cross-border workers, who also received most of their support from people living abroad ( 7 cross-border and 8 transnational). In both cases, it is nonetheless interesting that newcomers have no less than 4 ties with natives that give them important sources of support.

So far, the data confirm the mixed embeddedness of migrants, with the time of residence affecting the degree of transnationalism in the network. Interestingly however, natives showed a quite similar mixed embeddedness as the more established migrants: Their support was provided by on average 9 native Andorrans $(53 \%)$ and 8 migrants (47\%). Again, this finding reflects quite well the general composition of the Andorran population. They also received support from on average 8 people living abroad (cross-border and further away), which means that support received by migrants was slightly more local than support received by the Andorrans in our sample.

If we now focus on the support that each type of network member provides, we can see slight differences between the supportive functions of natives, local and transnational compatriots and other immigrants in the network. Among the Andorran respondents, natives were more often partners and they gave more legal and emotional help than migrants. Transnational ties supplied primarily logistic support. Among migrants, natives were more often figureheads and they provided more legal help than the other groups. Emotional support was remarkably given by both Andorrans and coethnics, against our expectations. If transnational ties were mentioned, these primarily had emotional functions. 
Judith Pampalona, Miranda J Lubbers y José Luis Molina, Mixed embeddedness of immigrant entrepreneurs in microstates. The case of Andorra.

Perifèria 24(1), junio 2019 revistes.uab.cat/periferia

Whereas our description so far focuses on average tendencies, it is good to take into account that we observed a large variability of network strategies and functions around those averages. To explore this better, we will now describe three different cases in depth, covering a part of the variety of networks among entrepreneurs in Andorra. We will focus on the support functions and mechanisms of the networks and on the informal economic activities that this social support allows to perform.

\section{The Andorran partner}

The first case we describe is that of Jordi, who has the Andorran nationality. As we observed in many cases, it was his father who created the current family business after having migrated to Andorra to make a living.

Jordi was born in Barcelona and he arrived in Andorra in 1975 as a child. He has received his education in Andorra and obtained the nationality in the 1990s, when he had already finished his graduate studies. From 1975 onwards, his father owned a jewellery shop in Andorra, where he sold self-made products and luxury products to tourists. This was the most favourable period of Andorra in economic terms. In Jordi's youth, the family had several establishments.

Nowadays, it is Jordi himself who manages the business although the shop does not sell self-made products anymore and they only maintain one of several establishments. In addition, Jordi now manages two other businesses: one of them is an online communication initiative and the other is a distribution company of luxury products. Both of these businesses are established with partners and employees abroad, as transnational collaborations are crucial to operate in other countries. Nevertheless, Jordi's residence in Andorra is essential to make the operation possible within the Principality.

The communication initiative employs three people in two geographical locations: Barcelona and Andorra. Jordi explains: 'As it is an online business, it is possible to make it work with a small but well-connected team'. The distribution company works with a large team distributed among different countries such as Morocco, France and Spain. 
Judith Pampalona, Miranda J Lubbers y José Luis Molina, Mixed embeddedness of immigrant entrepreneurs in microstates. The case of Andorra.

Perifèria 24(1), junio 2019 revistes.uab.cat/periferia

As it happens in many similar cases to Jordi's, we find a dispersed network with contacts settled in different countries: In this case Morocco, Spain, Andorra and France (see Figure 1). The larger nodes that are located in the centre of the network are the closest to ego and those who helped him at the very beginning of his business initiative: family and very close friends who have been collaborating with the family business since a long time ago. These close contacts are from Andorra and Barcelona (Spain). Also, as many of them are from Andorra and they collaborate with the business (the jewellery shop), they have several linkages among them.

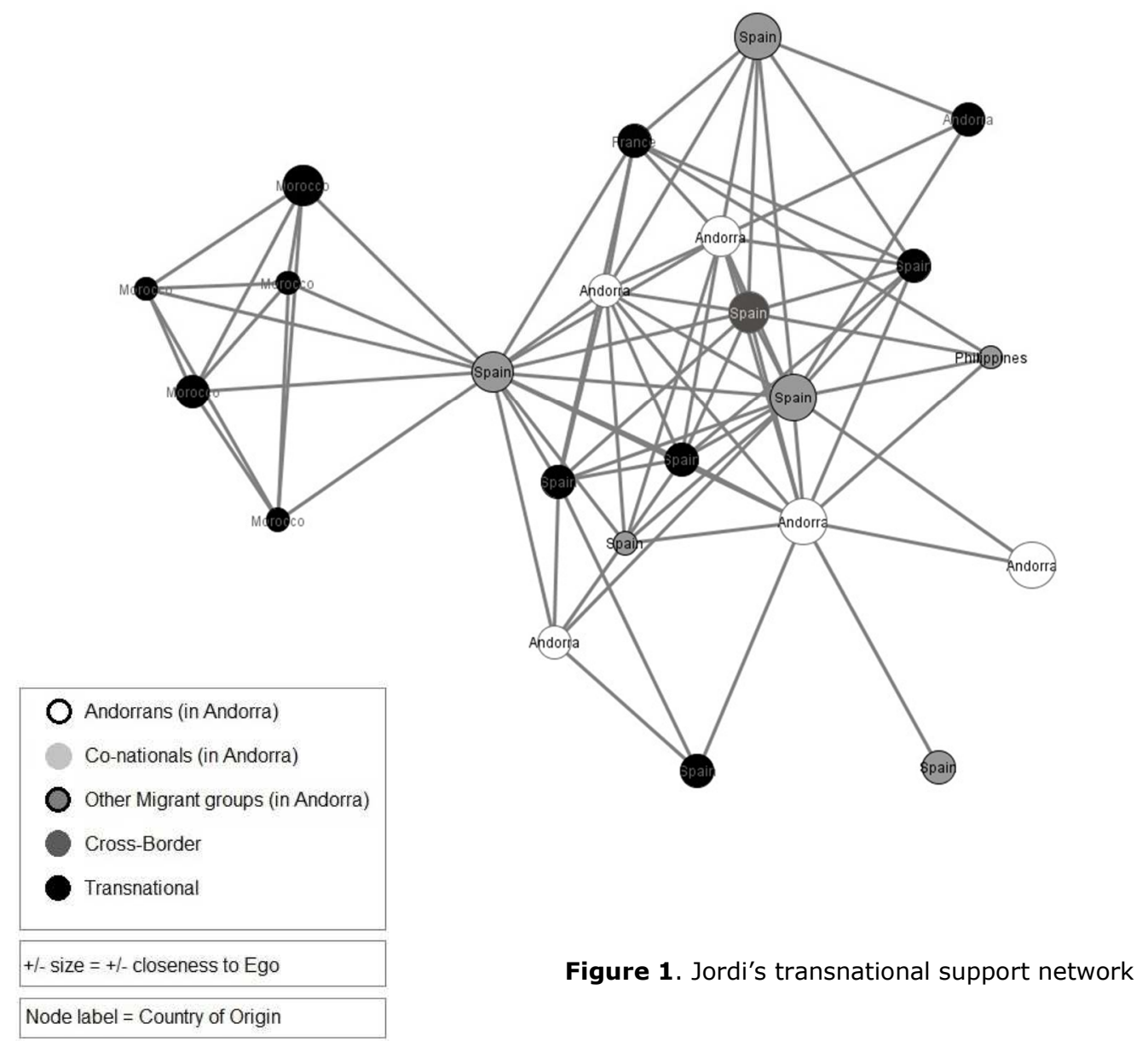


Judith Pampalona, Miranda J Lubbers y José Luis Molina, Mixed embeddedness of immigrant entrepreneurs in microstates. The case of Andorra.

Perifèria 24(1), junio 2019 revistes.uab.cat/periferia

The contacts in the network periphery are weaker, as indicated by the smaller node size. These nodes are representing people collaborating with the transnational business and the communication initiative. Most of these contacts are transnational. In the network periphery, we find some Andorran collaborators who are separated from the network core, although being connected to it. These contacts give some advice to the entrepreneur in very specific situations, but they are not connected to other daily collaborators.

There is an Andorran contact who acts as the linkage between the different groups and businesses. She is the coordinator and administrative assistant of Jordi, and her job is to organize the different initiatives. This agent is the person with the highest 'betweenness centrality' (i.e., the largest intermediating role) within Jordi's network though not the closest one to him in personal terms.

Jordi himself also has a high betweenness centrality in his geographically dispersed network, which appeared to be very usual in the case of transnational entrepreneurs. In our research, we found that most transnational entrepreneurs have the Andorran nationality as this is needed to be the legal representative agent in Andorra because of the established legal conditions. Also, this is related to the size of the country as some Andorran entrepreneurs of large size companies explained during the interview:

'When you have a successful business in a small country like this one, you arrive soon at a legal limit and you can't continue. Then, you look for other options and one of the most common is to collaborate with other entrepreneurs abroad. Then you have the opportunity of growing up as an entrepreneur, and your new partner has the option of operating in Andorra' (Participant 1, Andorran).

Nevertheless, a few established migrants basically focused on the tourism sector also had networks with relevant transnational dimensions. Apart from them, as we indicated before, the newcomers in Andorra also have highly transnational networks, but this is more due to their origin. 
Judith Pampalona, Miranda J Lubbers y José Luis Molina, Mixed embeddedness of immigrant entrepreneurs in microstates. The case of Andorra.

Perifèria 24(1), junio 2019 revistes.uab.cat/periferia

\section{A family business in the centre of the capital}

Aloke, an Indian man, arrived in Andorra as a child and he spent all his school years in Andorra. His parents decided to migrate and they arrived to Andorra, where they knew some people. Aloke's father was an employee for some years and then he decided to start his own business, an electronics store (as is quite common among Indian shop owner cases in Andorra). Of course, he needed a figurehead in order to be able to start the shop in Andorra, as he had been living there for just a few years. When Aloke grew up, he worked in the shops every weekend and school holiday.

'At the end, I hated the family business and I didn't want to work there anymore... so when I finished my studies I wanted to pursue a job, which would be completely different from my family's' Aloke remembered.

'After having had three different jobs, my father asked me to be a partner within the business and I accepted, so in the end I have been part of the family business for eight years'.

Aloke's personal network presents a dense structure in terms of the linkages among the different contacts appearing in it (see Figure 2). These contacts live in Andorra and they tend to be close to the respondent in most cases:

'Our business is directed to two different target groups: tourists who come from abroad on the weekends (usually Spanish, Russian or French) and also people from Andorra, who are usually considered as friends as they are very regular customers'.

Though many ties exist among the different nodes in the network, there is a more cohesive and interconnected group at the core of the graph. This group represents the family members and the current employees of the shops (four Spaniards and one Indian who is a family member), all of them very close contacts who all know each other. 
Judith Pampalona, Miranda J Lubbers y José Luis Molina, Mixed embeddedness of immigrant entrepreneurs in microstates. The case of Andorra.

Perifèria 24(1), junio 2019 revistes.uab.cat/periferia
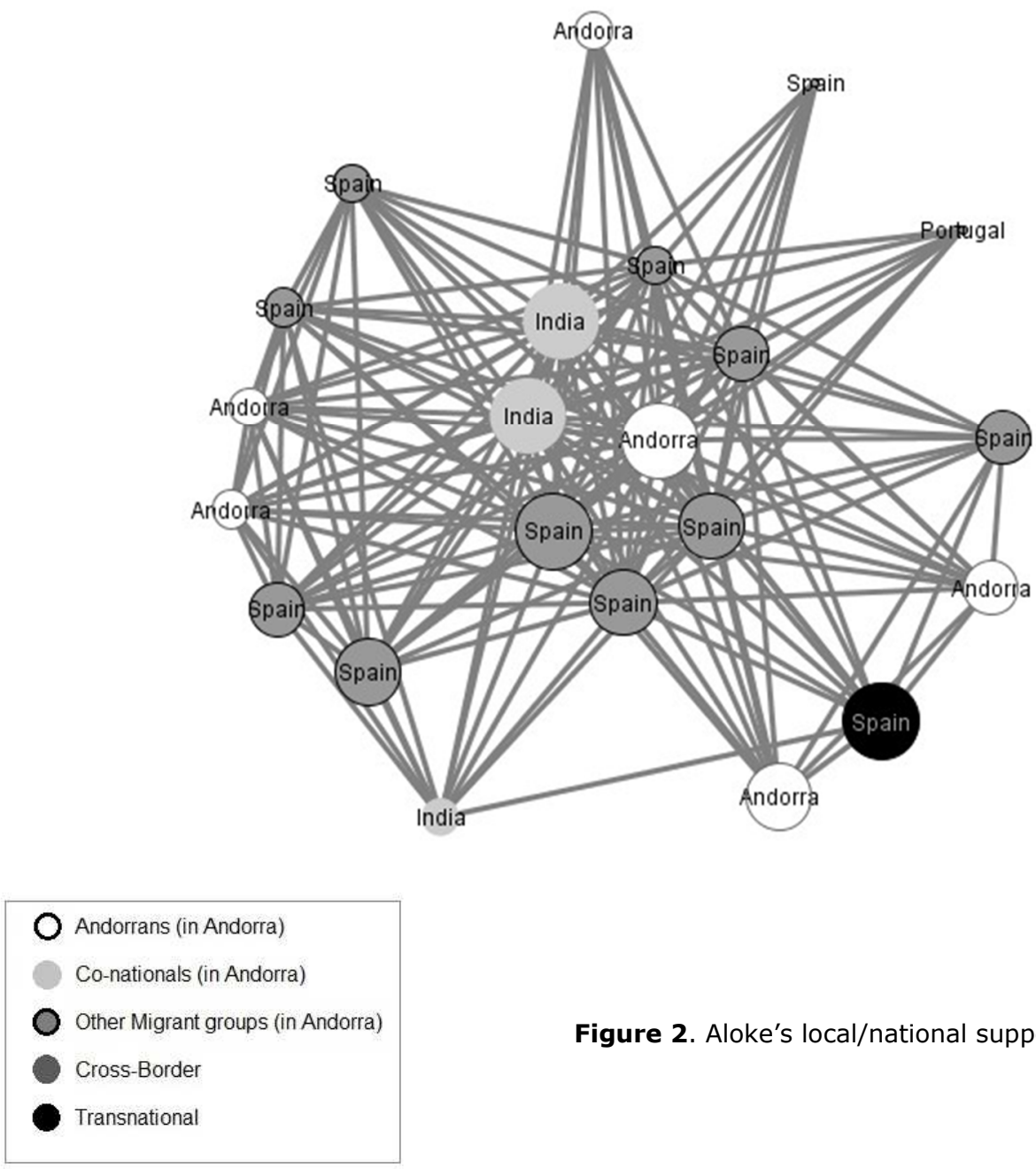

+ - size $=+$ /- closeness to Ego

Node label $=$ Country of Origin

In the periphery, several customers/friends and collaborators are also represented. With some exceptions, almost all of them are close contacts as they have had a relationship with Aloke since a long time ago and consequently they are connected to the core of the network. The appearing weak ties are representing other kind of collaborations such as the figurehead (who does not have a direct relationship to the business, though he has been an important support source at the beginning of the 
Judith Pampalona, Miranda J Lubbers y José Luis Molina, Mixed embeddedness of immigrant entrepreneurs in microstates. The case of Andorra.

Perifèria 24(1), junio 2019 revistes.uab.cat/periferia

business) and product suppliers. On the other hand, it is important to take into account that another main reason for the density of the network is the size of the context as all of them are established in Andorra la Vella so it is easy for them to know each other independently of Aloke or his family. The network only has one node that does not live in Andorra, the large, light blue node in the periphery representing Aloke's girlfriend who lives in a Spanish village very close to Andorra.

Many small businesses owned by immigrants in Andorra tend to have this structure due to two main factors: (a) the reduced size of the context, which facilitates the creation of ties and the access to social capital resources (what makes the structure of the network being so dense in many cases) and (b) the legislative restrictions existing within the country until 2012, which have affected thousands of similar cases to Aloke's (causing the appearance of many contacts established in the Andorran context and also causing contacts in the country of origin to only have a role in terms of emotional support).

According to this network model, it seems that immigrant entrepreneurs in a reduced and restricted context like Andorra need local support in order to be able to run a business, among others because otherwise they have to wait a long period (10-20 years) to create their own initiative. Actually, this is the model that we observed in $60 \%$ of immigrant entrepreneurs. Their network contacts are mostly settled within the national context, and they tend to be Andorran and of other nationalities, but not necessarily from the same community as the entrepreneur. Three informants commented on this:

'In this country it is quite easy to know people and get help from them.

And thank god this is like that! Because laws do not help newcomers at all, and you need to have Andorran friends from the beginning' (Participant 3, Portuguese).

'When you arrive at a place, you have to be social. If you are good to people, people will be good to you. And this is what I did when I arrived. And this is like wood: you have to work on it day by day, and then it is 
Judith Pampalona, Miranda J Lubbers y José Luis Molina, Mixed embeddedness of immigrant entrepreneurs in microstates. The case of Andorra.

Perifèria 24(1), junio 2019 revistes.uab.cat/periferia

strong and trustable. And in Andorra it is crucial to be good with your neighbours' (Participant 4, Indian).

More precisely, social capital resources are usually crucial to run a business across different contexts, however this is even more evident when restricted legislations are applied since the entrepreneur needs to have not only social support from his/her own collective, but also from natives and, in addition, this social support requires a certain closeness between both parts as informal and risky support is given (To be a figurehead is illegal). Though this situation seems to be somehow unreachable, 33\% of the immigrant informants in our study took this option instead of waiting for the regulatory period of residence to end (and $40 \%$ of the immigrants falling under the old laws). The small dimensions of the context and the small population help to gain access faster to these resources.

\section{A restaurant in the border: Playing both sides}

Penelope was born in the north-west of Spain, and when she finished her basic school and got married she decided to move to Andorra with her husband to make a living, like many Spanish immigrants in the 70s. At the beginning, both of them started to work in a hotel, and she had to combine her job with the care for the children and household chores.

'It was very hard for women in that time since we had to work out of home and the family and household were also our responsibility. Luckily, this is starting to change nowadays'.

'Later, we started to run a hotel in the centre of Andorra la Vella where we were working during several years and there we made a lot of contacts from the hotel trade. Of course, while we were running this business, we counted on the collaboration of a figurehead. This person was our ancient boss in the previous hotel we were working in'.

A few years later, they started to work in the primary sector (agriculture) being tenant farmers. They were working in that farm during 20 years 'I really loved this job since although it was hard, it was possible to work in your own way and speed'. 
Judith Pampalona, Miranda J Lubbers y José Luis Molina, Mixed embeddedness of immigrant entrepreneurs in microstates. The case of Andorra.

Perifèria 24(1), junio 2019 revistes.uab.cat/periferia

At last, they decided to end with this work as they had three offers to run different restaurants '(...) and we decided to take this one, because we liked the idea of being in a quite isolated place and the conditions were great for us'

Though having lived in Andorra for almost 40 years, Penelope and her husband never obtained the Andorran nationality since they have had enough support for maintaining the Spanish one with a resident legal condition in Andorra.

'As we have a lot of Andorran friends, many of our customers come from there and they speak about us to their friends or acquaintances'.

Nevertheless, an important part of the support comes from La Seu d'Urgell (a Spanish village which is at $10 \mathrm{~km}$ from the Andorran border) since because of being in Spanish territory they have to accomplish the Spanish law, which requires having employees from there. As a result, the support network combines contacts from both sides of the border, that is, legal residents in two different countries (see Figure 3) and so their legal conditions will be also different. In other words we would say that their actual area of residence area is the same although being divided by a border limit, which would also explain the network composition -with contacts placed in different countries-and the network structure -many connections among the contacts in the different places.

Most of Penelope's closest contacts reside in Andorra. These represent family members and very close friends (Andorrans and Spaniards) who have supported the business from the beginning in terms of emotional, logistical and even legal aid. Those who are in the centre as well but they have their residence in Spain (close to the border, in this case) are the employees of the restaurant. A couple of Andorran contacts are also employees, but their contract is informal and they just help or work in the restaurant when it is necessary in some weekends. Looking at the network periphery, some weak ties are found being both from Andorra la Vella and from La Seu d'Urgell (Spain). These weak contacts are very frequent customers, who supported the business not only in terms of an 'economic' relationship, but they also provided legal advice, logistic support or even promotion of the restaurant. 
Judith Pampalona, Miranda J Lubbers y José Luis Molina, Mixed embeddedness of immigrant entrepreneurs in microstates. The case of Andorra.

Perifèria 24(1), junio 2019 revistes.uab.cat/periferia

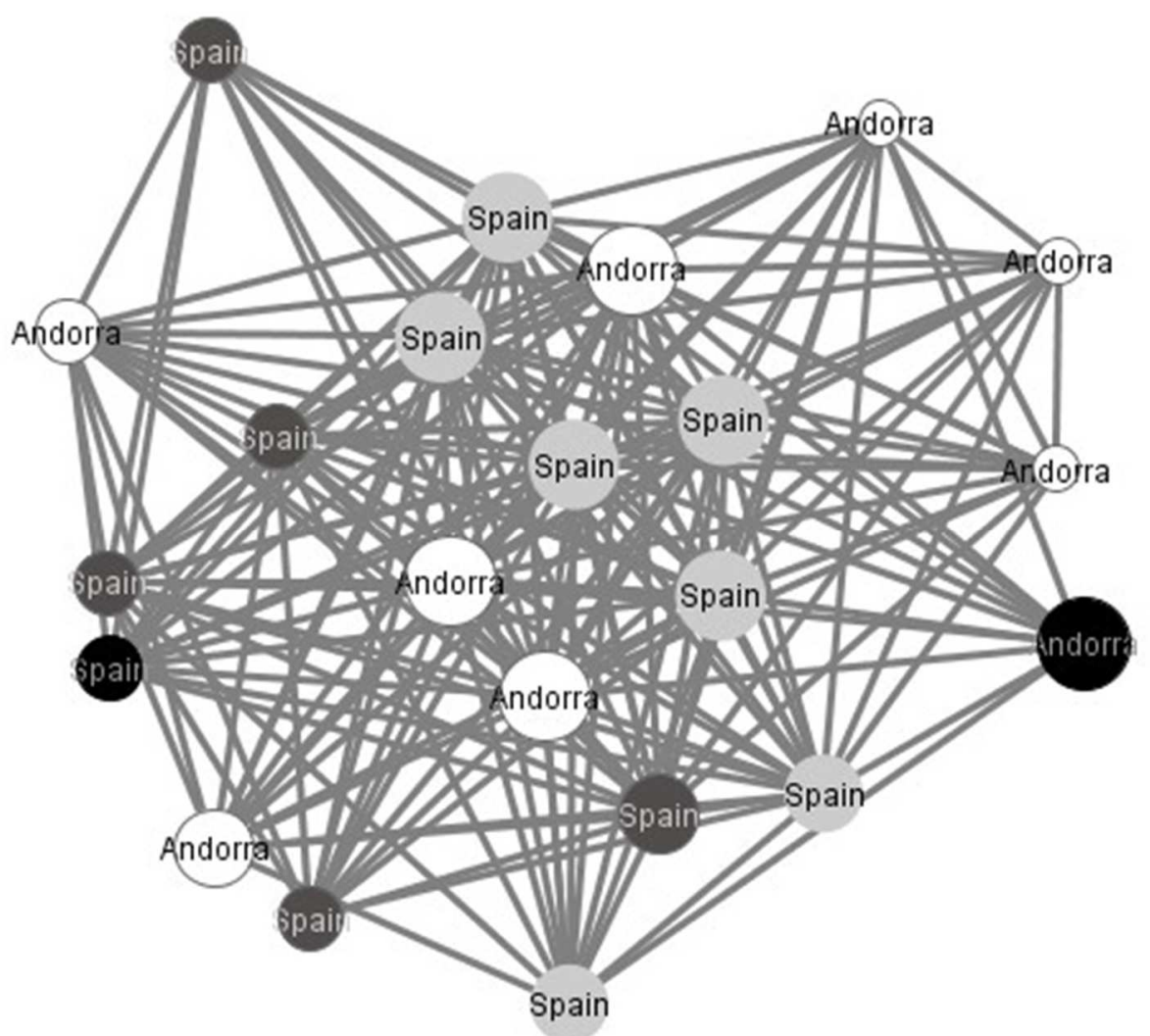

\footnotetext{
Andorrans (in Andorra)

Co-nationals (in Andorra)

Other Migrant groups (in Andorra)

Cross-Border

Transnational
}

+ - size $=+$ - closeness to Ego

Node label $=$ Country of Origin

Figure 3. Penelope's cross-border support network 
Judith Pampalona, Miranda J Lubbers y José Luis Molina, Mixed embeddedness of immigrant entrepreneurs in microstates. The case of Andorra.

Perifèria 24(1), junio 2019 revistes.uab.cat/periferia

We call this network model the cross-border profile. This profile appears to be a mixture of the previous two models, since we observe a concentrated network structure connecting what we could strictly call 'transnational' contacts. However, it is important to realize that they are not truly transnational contacts since they are located in a relatively small geographical area though being in different legal, national contexts. We propose the name of cross-border network for this kind of cases.

As we stated before, in a small country like Andorra it is important to take into account the role of the border since it determines certain conditions, whether legal or not, affecting people who are living there. One of the most usual cases is the large group of individuals who work in Andorra but live in Spanish and French villages close to the border. These individuals cross the border daily, and so they have a special legal condition: the cross-border workers.

In the case of entrepreneurs, this phenomenon happens in a different way. Whereas workers tend to cross the border from outside to inside the country to go to work, cross-border entrepreneurs cross the border from both sides and it is more delicate to deal with as it is not regulated. In addition, if entrepreneurs from abroad tried to operate in Andorra without being a resident or having an Andorran partner, this would be illegal. In case Andorran entrepreneurs try to operate abroad without any partner in the foreign country, then he/she must pay the taxes of both countries since no agreements are established. This loophole gives rise to informal economy activities, such as informal partnerships (two different businesses with their respective patrons legally working separately on both sides of the border but being in fact the same company), temporary employees with oral and informal agreements, and the sharing of material resources (in order not to pay customs duty every time they cross the border).

Due to these legal conditions (or restrictions) imposed by the presence of the border, businesses that are placed in the areas closest to the border tend to receive support from contacts on both sides. Some of these contacts also provide informal support 
Judith Pampalona, Miranda J Lubbers y José Luis Molina, Mixed embeddedness of immigrant entrepreneurs in microstates. The case of Andorra.

Perifèria 24(1), junio 2019 revistes.uab.cat/periferia

or even resources in order not only to make the business survive between two different legislations, but also to take the maximum advantage of this situation. This kind of 'cross-border' network also exists in cases where businesses have two partners (one on each side but both in the Pyrenees area) and they pretend to be two different companies whereas they are actually working together and sharing resources. This makes the network to be varied in terms of provenance of the contacts providing support but dense in terms of linkage structure since the geographical area is reduced and this make it easy to know the other people living in there. Two entrepreneurs explain the situation:

'My brother and I are Catalans, but our grandmother was Andorran. This is why my brother got the Andorran nationality and now we have 'two different businesses': one in Andorra and another one in La Seu d'Urgell. But in fact these 'two businesses' are the same and we share the obtained profits' (Participant 5, Catalan from the Catalan-Andorran border).

'If you have a business and you want to give a service to someone who is in Spain, it would be very expensive to pass all the things you need from one side of the border to the other. And you should do that very often! So that is why we collaborate with another company, which is in Spain, and we share the equipment we need without having to pay custom taxes. (...) To refuse Spanish work offers? We are in a huge economic crisis! We cannot refuse anything! (Participant 6, Spanish).

\section{Conclusions}

According to the described cases, immigrant entrepreneurs tend to have many contacts settled in Andorra. These contacts are usually nationals but they also include immigrants from their own nationality and others. Both the small size of the country and its population, together with the compulsory period of residence established by the law system, are the main explanations for this phenomenon. Nevertheless, similar structures were found in natives' networks, which cast doubt over the 
Judith Pampalona, Miranda J Lubbers y José Luis Molina, Mixed embeddedness of immigrant entrepreneurs in microstates. The case of Andorra.

Perifèria 24(1), junio 2019 revistes.uab.cat/periferia

application of the concept of mixed embeddedness to the microstate context. Furthermore, it is rather observed some nuances on the transnationalism degree in networks depending on the respondent situation characteristics. That is, whether he or she is a native in Andorra, a cross-border entrepreneur, a migrant (having started up a new business under legal constraints) or a new migrant.

On the other hand, the three analysed cases show that it is important to make a difference between the 'transnational' and 'cross-border' model as it can be seen that the structure of the network and its content change significantly. This fact demonstrates that three important aspects or elements exist in a microstate, affecting the networks of entrepreneurs: the size of the country, the established law system, and the general closeness to the border. These aspects limit the settlement of self-employed immigrants and the growth of their entrepreneurial activities, but at the same time they have a positive effect on their integration, and consequently on their success possibilities, which are larger because they know properly the operating market from the moment of starting the business.

It would be easy to think of a microstate as functioning as a city in terms of its socioeconomic structure, since the geographical area seems to be comparable to any reduced local economy at first appearance. However, this is not the case, as the law system and the given opportunity structure in labour and entrepreneurial terms is completely different in both contexts. Whereas a city is taking part in the structure of a larger country, the operating area will be more limited in microstates since the legislative jurisdiction is smaller and so are the possibilities to find business niches. Due to this fact, a large number of informal collaborations beyond the border exist in Andorran enterprises. According to our findings, these informal collaborative activities are carried out both by immigrants and by Andorrans, since no agreement exists between both countries to regulate businesses operating on both sides of the border. The most common situation of cross-border informal collaboration is actually when two allegedly different businesses are legally operating each on their side of the border, but they collaborate in terms of logistics and economic profits. Then, they can operate in two different legislative contexts without having to pay higher taxes. 
Judith Pampalona, Miranda J Lubbers y José Luis Molina, Mixed embeddedness of immigrant entrepreneurs in microstates. The case of Andorra.

Perifèria 24(1), junio 2019 revistes.uab.cat/periferia

Actually, this phenomenon can be visible in any border area; nevertheless, the presence of the border in microstates affects the whole country making these practices to be common in the whole jurisdictional area. Furthermore, the actual particularities of those small jurisdictions make their social and structural conditions change. Our research suggests that legislative restrictions applied in microstates make it more important for immigrant entrepreneurs to have the support of natives, since these are needed to develop economic activity, whereas immigrants settled in contexts with more permissive conditions tend to seek more collaborations in their co-ethnic or co-national communities to develop their economic activities (Salaff et al., 2003). This makes the legislative background to be one of the most important factors to explain the entrepreneurs' support and collaboration networks, since their structure and contents can change significantly depending on it.

The legislative restrictions concerning the economic rights of immigrants are probably the main reason for the common use of the figurehead in Andorra. Also, this phenomenon is probably the clearest example of the appearance of informal economy in this context. The relationship between an entrepreneur and his/her actual figurehead is usually supportive in the Andorran context, and this is probably due to the size of the country and the consequent ease to have close contacts with natives or longer-term residents who can already access the economic rights.

A limitation of this work is that the number of cases studied is low. Notwithstanding, the main goal of this project was not to obtain a representative overview of entrepreneurial networks in Andorra, but rather to understand the role played by support networks within entrepreneurial activities in microstate contexts; that is, to understand the underlying mechanisms that explain the functioning of networks in this particular context. We therefore opted for qualitative methods of case selection, seeking to maximize diversity (Small, 2008). However, we added a quantitative network module in order to allow comparison across the different cases. In this respect, it proved to be useful to know the existing connections between their support contacts so as to know whether they were embedded in densely or more sparsely connected networks. Also, it was interesting to analyse the contents of these 
Judith Pampalona, Miranda J Lubbers y José Luis Molina, Mixed embeddedness of immigrant entrepreneurs in microstates. The case of Andorra.

Perifèria 24(1), junio 2019 revistes.uab.cat/periferia

networks to see which is the most common type of support received and where does it come from.

Last, it is important to point out that Andorra is only one of six microstates in Europe and many other small recognized states exist in the world. All these small countries and jurisdictions tend to have particular features that are similar to the Andorran case, but obviously different in some aspects. Even though the obtained results show how important it is to take into account the particularities of any context in order to determine their effect on the social structure, it is necessary to explore immigrant and native entrepreneurs in other microstates in future research in order to have a comparative framework to confirm if the findings in this research are also applicable in there or, in any case, to precise in which concrete ways the context influences the support networks immigrant entrepreneurs as well as their business development strategies.

\section{Acknowledgements}

The corresponding author acknowledges a predoctoral grant from the Government of Andorra [ATC-008-AND/2011-2014] and a mobility grant from the Government of Andorra [AM2014-0018-AND].

This research is part of the project MINECO (CSO2012-32635)

The first author further expresses her gratefulness to the Centre on Migration, Policy and Society (University of Oxford) for providing her with support and facilities during the preparation of this paper.

\section{References}

Aldrich, H.E.\& Reiss, A. (1976). Continuities in the study of ecological succession; changes in the race composition of neighborhoods and their businesses. American Journal of Sociology, 81(4): 846- 866. DOI: https://doi.org/10.1086/226144 
Judith Pampalona, Miranda J Lubbers y José Luis Molina, Mixed embeddedness of immigrant entrepreneurs in microstates. The case of Andorra.

Perifèria 24(1), junio 2019 revistes.uab.cat/periferia

Aldrich, H.E. and Waldinger, R. 1990. 'Ethnicity and Entrepreneurship'. Annual

Review of Sociology 16: 111-135. DOI:

https://doi.org/10.1146/annurev.so.16.080190.000551

Arjona, Á. \& Checa, J.C. 2006. Empresariado extracomunitario en Almería: estructuras de oportunidad, características de grupo y estrategias étnicas. Reis 115: 297-317. DOI: https://doi.org/10.2307/40184774

Armstrong, H. W., \& Read, R. 2000. Comparing the economic performance of dependent territories and sovereign microstates. Economic Development and Cultural Change 48 (2): 285-306. DOI: https://doi.org/10.1086/452459

Baker, R. 1992. Scale and Administrative Performance: the Governance of Small States and Microstates. In Public administration in small and island states, edited by R. Baker, 5- 25. West Hartford, CT.: Kumarian Press. DOI: https://doi.org/10.1002/pad.4230130215

Baldacchino, G. 1993. Bursting the bubble: the pseudo-development strategies of microstates. Development \& Change 24 (1): 29-51. DOI: https://doi.org/10.1111/j.1467-7660.1993.tb00476.x

Cain, T. and Spoonley, P. 2013. Making it Work: The Mixed Embeddedness of Immigrant Entrepreneurs in New Zealand. IZA Discusion Paper Series 7332. DOI: http://ftp.iza.org/dp7332.pdf.

Churchill, N. C., \& Lewis, V. L. 1983. The Five Stages of Small Business Growth'. Harvard Business Review 3(61): 30-49.

Creswell, J. 2003. Research Design. Qualitative, Quantitative and Mixed Methods Approaches (2nd. edition). London: Sage.

Granovetter, M.S. 1973. 'The Strength of Weak Ties', American Journal of Sociology 78 (6): 1360-1380. DOI: https://doi.org/10.1086/225469

Grydehøj, A. 2011. Making the Most of Smallness: Economic Policy in Microstates and Sub-national Island Jurisdictions. Space and Polity 15(3): 183-196. DOI: https://doi.org/10.1080/13562576.2011.692578 
Judith Pampalona, Miranda J Lubbers y José Luis Molina, Mixed embeddedness of immigrant entrepreneurs in microstates. The case of Andorra.

Perifèria 24(1), junio 2019 revistes.uab.cat/periferia

Guarnizo, L.E. 2003. The economics of transnational living. International Migration Review 37(3): 666-699. DOI: https://doi.org/10.1111/j.17477379.2003.tb00154.x

Hart, K. 1973. Informal Income Opportunities and Urban Employment in Ghana, The journal of Modern African Studies 1 (11): 61- 89.

Jones, T., Ram, M., Edwards, P., Kiselinchev, A., \& Muchenje, L. 2012. New Migrant Enterprise: Novelty or Historical Continuity?. Urban Studies 49: 3159-3176. DOI: https://doi.org/10.1177/0042098012439109

Jónsson, Ö.D. and Saemundsson, R.J. 2006. Isolation as a Source of Entrepreneurial Opportunities: Overcoming the Limitations of Isolated Micro-States. In International Research in the Business Disciplines-Developmental Entrepreneurship: Adversity, Risk and Isolation.(pp. 217-233). Bingley: Elsevier. DOI: https://doi.org/10.1016/s1074-7877(06)05012-4

Kloosterman, R.C. 2010. Matching opportunities with resources: A framework for analysing migrant. entrepreneurship from a mixed embeddedness perspective. Entrepreneurship \& Regional Development 22 (1): 25-45. DOI: https://doi.org/10.1080/08985620903220488

Kloosterman, R.C., Van Der Leun, J. and Rath, J. 1999. Mixed embeddedness: (In)formal economic activities and immigrant businesses in the Netherlands. International Journal of Urban and Regional Research 23 (2): 252-266. DOI: https://doi.org/10.1111/1468-2427.00194

Krebs, V. \& Holley, J. 2002. Building Sustainable Communities through Network Building. Available at: http://www.orgnet.com/BuildingNetworks.pdf

Krosnick, J.A. \& Narayan, S. 1996. Satisfacting in surveys: Initial Evidence. New Directions for Evaluation 70: 29-44. DOI: https://doi.org/10.1002/ev.1033

Kurtoglu, F. 2007. Immigrant entrepreneurs in Austria. In Handbook of Research on Ethnic Minority Entrepreneurship. A Co-evolutionary view on Resource 
Judith Pampalona, Miranda J Lubbers y José Luis Molina, Mixed embeddedness of immigrant entrepreneurs in microstates. The case of Andorra.

Perifèria 24(1), junio 2019 revistes.uab.cat/periferia

Management (pp. 425- 433). Northampton: Edward Elgar Publishing Ltd.

DOI: https://doi.org/10.4337/9781847209962.00035

Light, I. \& Gold, S. 2000. Ethnic Economies. San Diego: Academic Press.

Lin, N. 2001. Social capital: a theory of social structure and action. New York: Cambridge University Press.

Mahuteau, S., Piracha, M., Tani, M. and Lucero, M.V. 2011. Immigration Policy and Entrepreneurship. IZA Discussion Paper Series 6238. http://ftp.iza.org/dp6238.pdf

Portes, A., Guarnizo, L.E. and Landolt, P. 1999. The Study of Transnationalism: Pitfalls and Promise Fan Emergent Research Field. Ethnic and Racial Studies 22: 217- 237. DOI: https://doi.org/10.1080/014198799329468

Price, M. \& Chacko, E. 2009. The Mixed Embeddedness of Ethnic Entrepreneurs in a New Immigrant Gateway. Journal of Immigrant \& Refugee Studies 7 (3): 328346. DOI: https://doi.org/10.1080/15562940903150105

Pütz, R., Schreiber, V. and Welpe, I. 2007. Ethnicity, Gender and Entrepreneurship: Turkish Entrepreneurs in Germany. In Handbook of Research on Ethnic Minority Entrepreneurship. A Co-evolutionary view on Resource Management (pp. 488- 511). Northampton: Edward Elgar Publishing Ltd. DOI: https://doi.org/10.4337/9781847209962.00039

Raijman, R. \& Tienda, M. 2003. Ethnic foundations of economic transactions: Mexican and Korean immigrant entrepreneurs in Chicago. Ethnic and Racial Studies 26 (5): 783-801. DOI: https://doi.org/10.1080/0141987032000109032

Ram, M., \& Jones, T. 2008. Ethnic minority businesses in the UK: An overview. Migrações Journal, 18 (3): 61-71.

Ram, M., Theodorakopoulos, N. \& Jones, T. 2008. Forms of capital, mixed embeddedness and Somali enterprise. Work, Employment \& Society, 22 (3): 427-446. DOI: https://doi.org/10.1177/0950017008093479 
Judith Pampalona, Miranda J Lubbers y José Luis Molina, Mixed embeddedness of immigrant entrepreneurs in microstates. The case of Andorra.

Perifèria 24(1), junio 2019 revistes.uab.cat/periferia

Renooy, P.H. 1990. The Informal Economy: Meaning, Measurement and Social Significance. Amsterdam: Netherlands Geographical Studies.

Salaff, J., Xu, L., Ping, L. 2003. Ethnic Entrepreneurship, Social Networks and the Enclave. In Approaching Transnationalism: Transnational Societies, Multicultural Contacts and Imaginings of Home. Boston: Kluwer Academic Publishers. DOI: https://doi.org/10.1007/978-1-4419-9220-8 4

Sassen, S. 1994. Cities in a World Economy. USA: Pine Forge Press.

Sepulveda, L., Syrett, S., \& Lyon, F. 2011. Population superdiversity and new migrant enterprise: the case of London. Entrepreneurship \& Regional Development 23: 469- 497. DOI: https://doi.org/10.1080/08985620903420211

Shane, S. \& Venkatamaran, S. 2000. The Promise of Entrepreneurship as a Field of Research. Academy of Management Review 25: 217- 226.

Small, M.L. 2008. Lost in Translation: How Not to Make Qualitative Research More Scientific. In Workshop on interdisciplinary Standards for Systematic Qualitative Research (pp. 165- 171). Washington D.C: National Science Foundation.

Valenzuela-García, H., Molina, J.L., Lubbers, M., García-Macías, A., Pampalona, J., \& Lerner, J. 2014. On Heterogeneous and Homogeneous Networks in a Multilayered Reality: Clashing Interests in the Ethnic Enclave of Lloret de Mar'. Societies 4 (1): 85-104. DOI: https://doi.org/10.3390/soc4010085

Waldinger, R. 1986. Immigrant enterprise: A critique and reformulation'. Theory and society, 15, (1): 249-285. DOI: https://doi.org/10.1007/bf00156934

Wilpert, C. 2003. Racism, Discrimination and Citizenship: The need for Antidiscrimination legislation in the Federal Republic of Germany. In Challenging Racism and Discrimination in Britain and Germany (pp. 245-269). Basingstoke: Palgrave Macmillan. DOI: https://doi.org/10.1057/9780230506206 14 